Вісник Харківського національного університету імені В.Н. Каразіна Серія "Математика, прикладна математика і механіка" Том 90,2019 , с. $26-41$

УДК 517.9
Visnyk of V.N.Karazin Kharkiv National University Ser. "Mathematics, Applied Mathematics and Mechanics"

Vol. 90, 2019, p. 26-41

DOI: $10.26565 / 2221-5646-2019-90-02$

\title{
Boundary value problems for systems of non-degenerate difference-algebraic equations
}

\author{
S.M. Chuiko, Ya.V. Kalinichenko, N.V. Popov \\ Donbass State Pedagogical University, Donetsk region, \\ Slavyansk, st. General Batyuk, 19, 84 116, Ukraine \\ chujko-slav@ukr.net, kalinichenkoddpu@ukr.net,ax.nikita@gmail.com
}

The conditions of existence and the construction of solutions of Cauchy problem for difference-algebraic system are determined. The conditions of existence and the construction of solutions of a linear Noetherian difference-algebraic boundary-value problem are determined. An original classification and a single scheme of construction of the solutions of difference-algebraic equations are proposed.

Keywords: boundary-value problems, difference-algebraic equations, pseudoinverse matrices.

Чуйко С.М., Калініченко Я.В., Попов М.В. Крайові задачі для систем невироджених різницево-алгебраїчних рівнянь. Знайдено умови розв'язності, а також конструкцію узагальненого оператора Гріна задачі Коші для різницево-алгебраїчної системи. Знайдено умови розв'язності, а також конструкцію узагальненого оператора Гріна для лінійної нетерової різницево-алгебраїчної крайової задачі. Запропоновано оригінальну класифікацію критичних і некритичних випадків для лінійних різницевоалгебраїчних крайових задач.

Ключові слова: крайові задачі, різницево-алгебраїчні рівняння, псевдообернена матриця.

Чуйко С.М., Калиниченко Я.В., Попов Н.В. Краевые задачи для систем невырожденных разностно-алгебраических уравнений. Найдены условия разрешимости, а также конструкция обобщенного оператора Грина задачи Коши для разностно-алгебраической системы. Найдены условия разрешимости, а также конструкция обобщенного оператора Грина для линейной нетеровой разностно-алгебраической краевой задачи. Предложена оригинальная классификация критических и некритических случаев для линейных разностно-алгебраических краевых задач.

Ключевые слова: краевые задачи, разностно-алгебраические уравнения, псевдообратные матрицы.

2010 Mathematics Subject Classification: 15A24, 34B15, 34C25.

\section{Introduction}

The relevance of the study of solvability conditions, as well as finding solutions of linear Noetherian difference-algebraic boundary-value problems is associated

(c) S. M. Chuiko, Ya. V. Kalinichenko, M. V. Popov, 2019 
with the widespread use of difference-algebraic boundary-value problems obtained by linearization of nonlinear Noetherian boundary-value problems for systems of ordinary differential and difference equations. The relevance of studying Noetherian boundary value problems in critical cases, in turn, is associated with numerous applications in electronics, mechanics, the theory of motion stability, biology and radio engineering, and the theory of nonlinear oscillations.

In part 1 the conditions of existence and the construction of solutions of Cauchy problem for linear nondegenerate difference-algebraic system are determined. In part 2 the conditions of existence and the construction of solutions of a linear Noetherian difference-algebraic boundary-value problem are determined. In part 3 the conditions of reduction of a difference-algebraic boundary value problem to a non-critical case are determined. The proposed conditions of solvability, as well as the scheme of finding solutions of linear Noetherian difference-algebraic boundary value problems are illustrated in detail in the examples.

\section{Nondegenerate systems of linear difference-algebraic equations}

Consider the problem of finding bounded solutions $[1,1]$

$$
z(k) \in \mathbb{R}^{n}, \quad k \in \Omega:=\{0,1,2, \ldots, \omega\}
$$

of the system of linear algebraic difference equations

$$
A(k) z(k+1)=B(k) z(k)+f(k) ;
$$

here $A(k), B(k) \in \mathbb{R}^{m \times n}$ are assumed, generally speaking, rectangular: $m \neq n$ matrices and $f(k)$ is real column vector. The matrix $A(k)$ is assumed rectangular or square but singular.

The problem of finding bounded solutions $z(k)$ of boundary value problem for a linear nondegenerate system of first-order difference equations

$$
z(k+1)=A(k) z(k)+f(k), \quad \ell z(\cdot)=\alpha \in \mathbb{R}^{v}
$$

was solved by A.A. Boichuk. Thus, the problem of finding bounded solutions $z(k)$ of a difference-algebraic system (1) is a generalization of the problem solved by A.A. Boichuk [1]. Denote $P_{A^{*}}(k)$ the matrix-orthoprojector [2]:

$$
P_{A^{*}}(k): \mathbb{R}^{m} \rightarrow \mathbb{N}\left(A^{*}(k)\right) .
$$

Provided [3] that the matrices $A^{+}(k) B(k), A^{+}(k) f(k)$ are bounded, and also

$$
P_{A^{*}(k)}=0
$$

the system (1) can be reduced to the traditional system of linear difference equations

$$
z(k+1)=A^{+}(k) B(k) z(k)+\mathfrak{F}_{0}\left(k, \nu_{0}(k)\right) ;
$$

here

$$
\operatorname{rank} A(k):=\sigma_{0}=m<n
$$


Besides,

$$
\mathfrak{F}_{0}\left(k, \nu_{0}(k)\right):=A^{+}(k) f(k)+P_{A_{\rho_{0}}}(k) \nu_{0}(k),
$$

$A^{+}(k)$ - is pseudoinverse (by Moore - Penrose), $P_{A_{\rho_{0}}}(k)-\left(n \times \rho_{0}\right)-$ is a matrix composed of $\rho_{0}$ linearly independent columns of $(n \times n)$ - orthoprojection matrix

$$
P_{A}(k): \mathbb{R}^{n} \rightarrow \mathbb{N}(A(k)),
$$

$\nu_{0}(k) \in \mathbb{R}^{\rho_{0}}$ is an arbitrary real vector function. General solution of the Cauchy problem

$$
z(0)=c \in \mathbb{R}^{n}
$$

for the homogeneous part of the system of difference equations (3)

$$
z(k)=X_{0}(k) c, \quad c \in \mathbb{R}^{n}
$$

is defined by the normal fundamental matrix:

$$
X_{0}(k+1)=A^{+}(k) B(k) X_{0}(k), \quad X_{0}(0)=I_{n} .
$$

The normal fundamental matrix can be represented as:

$$
X_{0}(k)=\prod_{j=1}^{k-1} A^{+}(j) B(j) .
$$

Under condition (2) the normal fundamental matrix $X_{0}(k)$ of the homogeneous part of the system of difference equations (3) is, generally speaking, singular:

$$
\operatorname{det} X_{0}(k)=0 \text {, }
$$

therefore, to construct a general solution of the Cauchy problem $z(0)=c \in \mathbb{R}^{n}$ for the inhomogeneous degenerate system of difference equations (3) the scheme $[1,5]$ is not applicable. However, the Green operator of the Cauchy problem for the degenerate system of difference equations (3) can be found as follows:

$$
\begin{gathered}
K\left[\mathfrak{F}_{0}\left(j, \nu_{0}(j)\right)\right](0):=0, \quad K\left[\mathfrak{F}_{0}\left(j, \nu_{0}(j)\right)\right](1):=\mathfrak{F}_{0}\left(1, \nu_{0}(1)\right), \ldots, \\
K\left[\mathfrak{F}_{0}\left(j, \nu_{0}(j)\right)\right](k+1):=A^{+}(k) B(k) K\left[\mathfrak{F}_{0}\left(j, \nu_{0}(j)\right)\right](k)+ \\
+\mathfrak{F}_{0}\left(k, \nu_{0}(k)\right), \ldots
\end{gathered}
$$

Thus, the following lemma is proved.

Lemma 1. The problem of finding bounded solutions of a system of linear difference-algebraic equations (1) under the condition (2) has a solution

$$
z(k)=X_{0}(k) c+K[f(j)](k), \quad c \in \mathbb{R}^{n} ;
$$


here $X_{0}(k)$ - is a normal fundamental matrix,

$$
K[f(j)](k):=K\left[\mathfrak{F}_{0}\left(j, \nu_{0}(j)\right)\right](k)
$$

- is the Green operator of the Cauchy problem for the system (1).

By analogy with the classification of differential-algebraic equations [3, 6], as well as with the classification of impulse boundary problems for ordinary differential equations $[2,7,8]$ under condition $(2))$, in the case of boundedness of matrices $A^{+}(k) B(k), A^{+}(k) f(k)$, we will say that the system of linear difference-algebraic equations (1) is degenerated. Note that, in contrast to the traditional system of linear difference equations [1], the solution of the system of linear differencealgebraic equations (1) under condition (2) depends on an arbitrary bounded vector function $\nu_{0}(k) \in \mathbb{R}^{\rho_{0}}$.

Example 1. Let's find a solution to the system of first-order differencealgebraic equations

$$
A z(k+1)=B z(k)+f(k), \quad k=0,1,2,3,
$$

where

$$
A:=\left(\begin{array}{cccc}
0 & 1 & 0 & 0 \\
-1 & 0 & 0 & 1 \\
0 & 0 & -1 & 0
\end{array}\right), B:=\left(\begin{array}{cccc}
0 & 1 & 0 & 0 \\
1 & 0 & 0 & 1 \\
0 & 0 & 1 & 0
\end{array}\right), f(k)=\left(\begin{array}{l}
1 \\
2 \\
3
\end{array}\right) .
$$

Since condition (2) is fulfilled and the system (4) has a solution of the form

$$
z(k)=X_{0}(k) c+K[f(j)](k), \quad c \in \mathbb{R}^{4} ;
$$

here $X_{0}(k)$ - is the normal fundamental matrix:

$$
\begin{gathered}
X_{0}(0)=I_{4}, \quad X_{0}(1)=\frac{1}{2}\left(\begin{array}{cccc}
-1 & 0 & 0 & -1 \\
0 & 2 & 0 & 0 \\
0 & 0 & -2 & 0 \\
1 & 0 & 0 & 1
\end{array}\right), \\
X_{0}(2)=\left(\begin{array}{llll}
0 & 0 & 0 & 0 \\
0 & 1 & 0 & 0 \\
0 & 0 & 1 & 0 \\
0 & 0 & 0 & 0
\end{array}\right), \quad X_{0}(3)=\left(\begin{array}{cccc}
0 & 0 & 0 & 0 \\
0 & 1 & 0 & 0 \\
0 & 0 & -1 & 0 \\
0 & 0 & 0 & 0
\end{array}\right) .
\end{gathered}
$$

Besides:

$$
K[f(j)](0):=0, \quad K[f(j)](1)=\left(\begin{array}{c}
-1 \\
1 \\
-3 \\
1
\end{array}\right),
$$




$$
K[f(j)](2)=\left(\begin{array}{c}
-1 \\
2 \\
0 \\
1
\end{array}\right), \quad K[f(j)](3)=\left(\begin{array}{c}
-1 \\
3 \\
-3 \\
1
\end{array}\right) .
$$

In this case, the matrix $A(k)$ - is rectangular, while $\rho_{0}=1 \neq 0$, therefore the solution found depends on an arbitrary continuous vector-function; in this case $\nu_{0}(k):=0$.

\section{Boundary value problems for systems of linear difference-algebraic equations}

We investigate the problem of finding bounded solutions $[1,1]$

$$
z(k) \in \mathbb{R}^{n}, \quad k \in \Omega
$$

linear Noetherian $(n \neq v)$ for the linear Noetherian boundary value problem for a system of linear difference-algebraic equations $[1,1]$

$$
A(k) z(k+1)=B(k) z(k)+f(k), \quad \ell z(\cdot)=\alpha, \quad \alpha \in \mathbb{R}^{v} ;
$$

here $A(k), B(k) \in \mathbb{R}^{m \times n}$ - are real matrices and $f(k)$ are real column vectors,

$$
\ell z(\cdot): \mathbb{R}^{n} \rightarrow \mathbb{R}^{v}
$$

is a linear bounded vector functional defined on a space of bounded functions. The problem of finding bounded solutions $z(k)$ of a boundary value problem for a linear non-degenerate system of first-order difference equations

$$
z(k+1)=A(k) z(k)+f(k), \quad \ell z(\cdot)=\alpha \in \mathbb{R}^{v}
$$

was solved by A.A. Boichuk [1]. Thus, the task (5) is a generalization of the problem solved by A.A. Boichuk [1]. According to Lemma 1, the problem of finding bounded solutions of a non-degenerate system of linear algebraic difference equations (5) subject to (2) has a solution

$$
z(k)=X_{0}(k) c+K\left[f(j), \nu_{0}(j)\right](k), \quad c \in \mathbb{R}^{n} ;
$$

here $X_{0}(k)$ - is a normal fundamental matrix,

$$
K\left[f(j), \nu_{0}(j)\right](k):=K\left[\mathfrak{F}_{0}\left(j, \nu_{0}(j)\right)\right](k)
$$

is the Green operator of the Cauchy problem for the system of differencealgebraic equations (5). Note that, unlike the traditional system of linear difference equations [1], the solution of the system of linear difference-algebraic equations (5) subject to condition (2) depends on an arbitrary bounded vector function $\nu_{0}(k) \in \mathbb{R}^{\rho_{0}}$; and we set this function to be fixed at the beginning. 
Denote the matrix $Q_{0}:=\ell X_{0}(\cdot) \in \mathbb{R}^{v \times n}$, and also

$$
P_{Q_{0}}: \mathbb{R}^{n} \rightarrow \mathbb{N}\left(Q_{0}\right), \quad P_{Q_{0}^{*}}: \mathbb{R}^{v} \rightarrow \mathbb{N}\left(Q_{0}^{*}\right)
$$

are orthoprojection matrices [1]. Substituting the general solution (6) of the Cauchy problem $z(0)=c \in \mathbb{R}^{n}$ of the inhomogeneous linear difference-algebraic equation (5) into the boundary condition (5), we get the equation

$$
Q_{0} c=\alpha-\ell K\left[f(j), \nu_{0}(j)\right](\cdot),
$$

solvable if and only if

$$
P_{Q_{0}^{*}}\left\{\alpha-\ell K\left[f(j), \nu_{0}(j)\right](\cdot)\right\}=0 ;
$$

in this case, the solution $z(k)$ of the linear Noetherian boundary value problem (5) is determined by the vector

$$
c=Q_{0}^{+}\left\{\alpha-\ell K\left[f(j), \nu_{0}(j)\right](\cdot)\right\}+P_{Q_{r}} c_{r}, \quad c_{r} \in \mathbb{R}^{r} .
$$

Here $Q_{0}^{+} \in \mathbb{R}^{n \times v}$ - is the Moore - Penrose pseudo-inverse matrix [1]; matrix $P_{Q_{r}} \in \mathbb{R}^{n \times r}$ is composed of $r$ linearly independent columns of the orthoprojection matrix $P_{Q_{0}} \in \mathbb{R}^{n \times n}$. Thus, the following lemma is proved.

Lemma 2. The problem of finding bounded solutions of the system of linear difference-algebraic equations (5) subject to (2) has a solution

$$
z(k)=X_{0}(k) c+K\left[f(j), \nu_{0}(j)\right](k), \quad c \in \mathbb{R}^{n} ;
$$

here $X_{0}(k)$ - is a normal fundamental matrix,

$$
K[f(j)](k):=K\left[\mathfrak{F}_{0}\left(j, \nu_{0}(j), \nu_{0}(j)\right)\right](k)
$$

- is the Green operator of the Cauchy problem for the system of differencealgebraic equations (5). The problem of finding bounded solutions of a linear Noetherian $(n \neq v)$ boundary value problem for the system of linear differencealgebraic equations (5) under conditions (2) and (7) has a solution

$$
z(k)=X_{r}(k) c_{r}+G\left[f(j), \nu_{0}(j), \alpha\right](k), \quad c_{r} \in \mathbb{R}^{r} ;
$$

here

$$
X_{r}(k):=X_{0}(k) P_{Q_{r}}, \quad k \in \Omega:=\{0,1,2, \ldots, \omega\}
$$

is a fundamental matrix of solutions of the homogeneous part of the problem (5) and

$$
G\left[f(j), \nu_{0}(j), \alpha\right](k):=K\left[\mathfrak{F}_{0}\left(j, \nu_{0}(j)\right)\right](k)+X_{0}(k) Q_{0}^{+}\left\{\alpha-\ell K\left[f(j), \nu_{0}(j)\right](\cdot)\right\}
$$


is the generalized Green operator of a linear Noetherian boundary value problem for the system of linear difference-algebraic equations (5).

Example 2. Let's find the solution of the linear boundary problem for the system of first order difference-algebraic equations

$$
A z(k+1)=B z(k)+f(k), z(0)-z(3)=\alpha, k=0,1,2,3,
$$

where

$$
\begin{gathered}
A:=\left(\begin{array}{cccc}
0 & 1 & 0 & 0 \\
-1 & 0 & 0 & 1 \\
0 & 0 & -1 & 0
\end{array}\right), B:=\left(\begin{array}{cccc}
0 & 1 & 0 & 0 \\
1 & 0 & 0 & 1 \\
0 & 0 & 1 & 0
\end{array}\right), \quad f(k)=\left(\begin{array}{l}
1 \\
2 \\
3
\end{array}\right), \\
\alpha:=\left(\begin{array}{cccc}
1 & -3 & 3 & -1
\end{array}\right)^{*} .
\end{gathered}
$$

Since condition (2) is satisfied, the system (8) has a solution of the form

$$
z(k)=X_{0}(k) c+K\left[f(j), \nu_{0}(j)\right](k), \quad c \in \mathbb{R}^{4} ;
$$

here $X_{0}(k)$ - is the normal fundamental matrix given in Example 1. In this case, the matrix $A(k)$ - is rectangular, and $\rho_{0}=1 \neq 0$, therefore, the solution found depends on an arbitrary bounded function; we set $\nu_{0}(k):=0$. Since the matrix

$$
Q_{0}=X_{0}(0)-X_{0}(3)=\left(\begin{array}{cccc}
1 & 0 & 0 & 0 \\
0 & 0 & 0 & 0 \\
0 & 0 & 2 & 0 \\
0 & 0 & 0 & 1
\end{array}\right)
$$

is degenerate, for the boundary value problem (8) the critical case is true: $P_{Q_{0}^{*}} \neq 0$, and the solvability condition (7) is fulfilled; here

$$
P_{Q_{0}^{*}}=P_{Q_{0}}=\left(\begin{array}{cccc}
0 & 0 & 0 & 0 \\
0 & 1 & 0 & 0 \\
0 & 0 & 0 & 0 \\
0 & 0 & 0 & 0
\end{array}\right), \quad P_{Q_{r}}=\left(\begin{array}{l}
0 \\
1 \\
0 \\
0
\end{array}\right) .
$$

The solution of the boundary value problem (8)

$$
z(k)=X_{r}(k) c_{r}+G\left[f(j), \nu_{0}(j), \alpha\right](k), \quad c_{r} \in \mathbb{R}^{1}
$$

determines the generalized Green operator of the boundary value problem (8)

$$
G\left[f(j), \nu_{0}(j), \alpha\right](k)=K\left[f(j), \nu_{0}(j)\right](k),
$$

and also

$$
X_{r}(k):=X_{0}(k) P_{Q_{r}}=P_{Q_{r}}, \quad k \in \Omega:=\{0,1,2,3\}
$$


is the fundamental matrix of solutions of the homogeneous part of the boundary value problem. (8).

Following the traditional classification of linear Noetherian boundary value problems $[1,7]$, the case of $P_{Q_{0}^{*}} \neq 0$ is called critical; in this case, the existence conditions and the form of the general solution of the problem of finding bounded solutions of the system of linear difference-algebraic equations (5) are determined by the proved Lemma 2 . The case $P_{Q_{0}^{*}}=0$ is said to be noncritical; in this case, the existence conditions and the form of the general solution of the problem of finding bounded solutions of the system of linear difference-algebraic equations (5) is determined by the following statement.

Corollary 1. The problem of finding bounded solutions of the system of linear difference-algebraic equations (5) subject to (2) has a solution

$$
z(k)=X_{0}(k) c+K\left[f(j), \nu_{0}(j)\right](k), \quad c \in \mathbb{R}^{n} ;
$$

here $X_{0}(k)$ - is a normal fundamental matrix,

$$
K[f(j)](k):=K\left[\mathfrak{F}_{0}\left(j, \nu_{0}(j), \nu_{0}(j)\right)\right](k)
$$

is the Green operator of the Cauchy problem for the system of difference-algebraic equations (5). The problem of finding bounded solutions of a linear Noetherian $(n \neq v)$ boundary value problem for a system of linear difference-algebraic equations (5) in the non-critical $P_{Q_{0}^{*}}=0$ case, under condition (2) has a solution

$$
z(k)=X_{r}(k) c_{r}+G\left[f(j), \nu_{0}(j), \alpha\right](k), \quad c_{r} \in \mathbb{R}^{r} ;
$$

here

$$
X_{r}(k):=X_{0}(k) P_{Q_{r}}, \quad k \in \Omega
$$

is the fundamental matrix of solutions of the homogeneous part of the boundary value problem (5) and

$$
G\left[f(j), \nu_{0}(j), \alpha\right](k):=K\left[\mathfrak{F}_{0}\left(j, \nu_{0}(j)\right)\right](k)+X_{0}(k) Q^{+}\left\{\alpha-\ell K\left[f(j), \nu_{0}(j)\right](\cdot)\right\}
$$

is the generalized Green operator of a linear Noetherian boundary value problem for a system of linear difference-algebraic equations (5).

Example 3. Let's find the solution of a linear two-point problem for a system of first-order difference-algebraic equations

$$
A z(k+1)=B z(k)+f(k), \ell z(\cdot)=0, k=0,1,2,3,
$$

where the matrixes $A, B$ and the function $f(k)$ are defined above in example 2. Besides

$$
\ell z(\cdot):=M(z(0)+z(3)), \quad M:=\left(\begin{array}{cccc}
1 & 0 & 0 & 0 \\
0 & 1 & 1 & 0 \\
0 & 0 & 0 & 1
\end{array}\right) .
$$


In this case, the matrix $A(k)$ - is rectangular, with $\rho_{0}=1 \neq 0$, therefore the solution found above in example 2 of the system of difference-algebraic equations (9) depends on an arbitrary continuous function; we set $\nu_{0}(k):=k$. Since the matrix

$$
Q_{0}=M\left(X_{0}(0)+X_{0}(3)\right)=\left(\begin{array}{cccc}
1 & 0 & 0 & 0 \\
0 & 2 & 0 & 0 \\
0 & 0 & 0 & 1
\end{array}\right)
$$

is of full rank, the noncritical case holds for the boundary value problem (9): $P_{Q_{0}^{*}} \neq 0$. The Green operator of the Cauchy problem for a system of differencealgebraic equations (9) has the form

$$
\begin{gathered}
K[f(j)](0):=0, \quad K[f(j)](1)=\left(\begin{array}{c}
-1 \\
1 \\
-3 \\
2
\end{array}\right), \\
K[f(j)](2)=\left(\begin{array}{l}
0 \\
2 \\
0 \\
4
\end{array}\right), \quad K[f(j)](3)=\left(\begin{array}{c}
0 \\
3 \\
-3 \\
6
\end{array}\right) .
\end{gathered}
$$

Since for the boundary value problem (9) there is a noncritical case, then, according to the corollary, the boundary value problem (9) is solvable. The decision of a boundary value problem (9)

$$
z(k)=X_{r}(k) c_{r}+G\left[f(j), \nu_{0}(j), \alpha\right](k), \quad c_{r} \in \mathbb{R}^{1}
$$

is defined by the Green operator for the boundary value problem (9)

$$
\begin{gathered}
G\left[f(j), \nu_{0}(j), \alpha\right](0)=\left(\begin{array}{c}
1 \\
1 \\
0 \\
-3
\end{array}\right), \quad G\left[f(j), \nu_{0}(j), \alpha\right](1)=\left(\begin{array}{c}
1 \\
2 \\
-3 \\
1
\end{array}\right), \\
G\left[f(j), \nu_{0}(j), \alpha\right](2)=\left(\begin{array}{c}
0 \\
3 \\
0 \\
4
\end{array}\right), \quad G\left[f(j), \nu_{0}(j), \alpha\right](3)=\left(\begin{array}{c}
0 \\
4 \\
-3 \\
6
\end{array}\right),
\end{gathered}
$$

And also

$$
X_{r}(0)=-X_{r}(1)=X_{r}(2)=-X_{r}(3)=\left(\begin{array}{l}
0 \\
0 \\
1 \\
0
\end{array}\right)
$$

is the fundamental matrix of solutions of the homogeneous part of the boundary value problem (9). 


\section{Reduction of a difference-algebraic boundary value problem to a non-critical case}

In the general case, namely, for an arbitrary real vector function

$$
\nu_{0}(k) \in \mathbb{R}^{\rho_{0}}
$$

the solvability of the linear Noetherian boundary value problem for the system of linear difference-algebraic equations (5) essentially depends on the choice of this function. Set

$$
\nu_{0}(k):=\Psi_{0}(k) \gamma, \quad \gamma \in \mathbb{R}^{\theta}
$$

here

$$
\Psi_{0}(k) \in \mathbb{R}^{\rho_{0} \times \theta}
$$

is an arbitrary real full rank matrix. The generalized Green operator of the Cauchy problem for a system of linear difference-algebraic equations (5) can be represented as

$$
K\left[f(j), \nu_{p}(j)\right](k)=K\left[A^{+}(j) f(j)\right](k)+K\left[\Psi_{0}(j)\right](k) \gamma
$$

here

$$
\begin{gathered}
K\left[\Psi_{0}(j)\right](0):=0, \quad K\left[\Psi_{0}(j)\right](1):=P_{A_{\rho_{0}}}(0) \Psi_{0}(0), \\
K\left[\Psi_{0}(j)\right](2):=A^{+}(1) B(1) K\left[\Psi_{0}(j)\right](1)+P_{A_{\rho_{0}}}(1) \Psi_{0}(1), \ldots, \\
K\left[\Psi_{0}(j)\right](k+1):=A^{+}(k) B(k) K\left[\Psi_{0}(j)\right](k)+P_{A_{\rho_{0}}}(k) \Psi_{0}(k) .
\end{gathered}
$$

Denote the matrix

$$
\mathcal{D}_{0}:=\left\{Q_{0} ; \ell K\left[\Psi_{0}(j)\right](\cdot)\right\} \in \mathbb{R}^{v \times\left(\rho_{0}+\theta\right)} .
$$

Substituting the general solution

$$
z(k)=X_{0}(k) c+K\left[f(j), \nu_{0}(j)\right](k), \quad c \in \mathbb{R}^{n}
$$

of the system of linear algebraic difference equations (5) into the boundary condition (5), we arrive at a linear algebraic equation

$$
\mathcal{D}_{0} \check{c}=\alpha-\ell K\left[A^{+}(j) f(j)\right](\cdot), \quad \check{c}:=\operatorname{col}\left(c_{\rho_{0}}, \gamma\right) \in \mathbb{R}^{\rho_{0}+\theta} .
$$

Equation (10) is solvable if and only if

$$
P_{\mathcal{D}_{0}^{*}}\left\{\alpha-\ell K\left[A^{+}(j) f(j)\right](\cdot)\right\}=0 .
$$


Here $P_{\mathcal{D}_{0}^{*}}$ is the ortoprojector: $\mathbb{R}^{v} \rightarrow \mathbb{N}\left(\mathcal{D}^{*}\right)$. Under condition (11) and only with it, the general solution of equation (10)

$$
\check{c}=\mathcal{D}^{+}\left\{\alpha-\ell K\left[A^{+}(j) f(j)\right](\cdot)\right\}+P_{\mathcal{D}} \delta, \quad \delta \in \mathbb{R}^{\rho_{0}+\theta}
$$

determines the general solution of the boundary value problem (5)

$$
\begin{aligned}
& z(k, \delta)=\left\{X_{0}(k) ; K\left[\Psi_{0}(j)\right](k)\right\} \mathcal{D}_{0}^{+}\left\{\alpha-\ell K\left[A^{+}(j) f(j)\right](\cdot)\right\}+ \\
& +K\left[A^{+}(j) f(j)\right](k)+\left\{X_{0}(k) ; K\left[\Psi_{0}(j)\right](k)\right\} P_{\mathcal{D}_{0}} \delta, \quad \delta \in \mathbb{R}^{\rho_{0}+\theta} .
\end{aligned}
$$

Here $P_{\mathcal{D}_{0}}$ is the orthoprojection matrix: $\mathbb{R}^{\rho_{0}+\theta} \rightarrow \mathbb{N}\left(\mathcal{D}_{0}\right)$. So the following theorem has been proved.

Theorem. The problem of finding bounded solutions of the system of linear difference-algebraic equations (5) subject to (2) has a solution

$$
z(k)=X_{0}(k) c+K\left[f(j), \nu_{0}(j)\right](k), \quad c \in \mathbb{R}^{n} .
$$

Under condition (11) and only with it, the general solution of the differencealgebraic boundary value problem (5)

$$
z\left(k, c_{r}\right)=X_{r}(k) c_{r}+G\left[f(j) ; \Psi_{0}(j) ; \alpha\right](k), \quad c_{r} \in \mathbb{R}^{r}
$$

defines a generalized Green operator for a difference-algebraic boundary value problem (5)

$$
\begin{gathered}
G\left[f(j) ; \Psi_{0}(j) ; \alpha\right](k):=K\left[A^{+}(j) f(j)\right](k)+ \\
+\left\{X_{0}(k) ; K\left[\Psi_{0}(j)\right](k)\right\} \mathcal{D}_{0}^{+}\left\{\alpha-\ell K\left[A^{+}(j) f(j)\right](\cdot)\right\} .
\end{gathered}
$$

The matrix $X_{r}(k)$ is composed of $r$ linearly independent columns of the matrix

$$
\left\{X_{0}(k) ; K\left[\Psi_{0}(j)\right](k)\right\} P_{\mathcal{D}_{0}} .
$$

Under condition $P_{\mathcal{D}_{0}^{*}} \neq 0$ we say that the difference-algebraic boundary value problem (5) is a critical case, and vice versa: under condition $P_{Q_{0}^{*}} \neq 0, P_{\mathcal{D}_{0}^{*}}=0$ we say that the difference-algebraic boundary value problem (5) is reduced to the non-critical case. The latter definition is a generalization of the critical case $\left(P_{Q^{*}}=0\right)$ for the Noetherian difference problem for the system obtained from system (5) with $A(k) \equiv I_{n}$, for the case in which the generalized Green operator of the Cauchy problem for difference-algebraic system (5) is dependent on an arbitrary vector function $\nu_{0}(k) \in \mathbb{R}^{\rho_{0}}$. 
Corollary 2. Under condition (2) the general solution of the differencealgebraic boundary value problem (5) is the folowing

$$
z\left(k, c_{r}\right)=X_{r}(k) c_{r}+G\left[f(j) ; \Psi_{0}(j) ; \alpha\right](k), \quad c_{r} \in \mathbb{R}^{r} .
$$

Example 3. Let's find the solution of the periodic boundary value problem for the system of first order difference-algebraic equations

$$
A z(k+1)=B z(k)+f(k), z(0)-z(4)=0, \quad k=0,1, \ldots, 4,
$$

where

$$
A:=\left(\begin{array}{llll}
1 & 0 & 0 & 0 \\
0 & 1 & 0 & 0 \\
0 & 0 & 1 & 0
\end{array}\right), \quad B:=\left(\begin{array}{cccc}
1 & -1 & 1 & 0 \\
0 & -2 & 5 & 1 \\
-2 & -1 & 4 & 0
\end{array}\right), \quad f(k):=\left(\begin{array}{c}
0 \\
\sin \frac{\pi k}{2} \\
0
\end{array}\right) .
$$

Since condition (2) is fulfilled, the system (12) has a solution of the form

$$
z(k)=X_{0}(k) c+K\left[f(j), \nu_{0}(j)\right](k), \quad c \in \mathbb{R}^{4} ;
$$

here

$$
X_{0}(k)=\left(\begin{array}{cccc}
\cos \frac{\pi k}{2}+\sin \frac{\pi k}{2} & -\sin \frac{\pi k}{2} & \sin \frac{\pi k}{2} & 0 \\
\cos \frac{\pi k}{2}+3 \sin \frac{\pi k}{2}-3^{k} & \cos \frac{\pi k}{2}-2 \sin \frac{\pi k}{2} & 2 \sin \frac{\pi k}{2}-\cos \frac{\pi k}{2}+3^{k} & 0 \\
\cos \frac{\pi k}{2}+\sin \frac{\pi k}{2}-3^{k} & -\sin \frac{\pi k}{2} & \sin \frac{\pi k}{2} & 0 \\
0 & 0 & 0 & 0
\end{array}\right)
$$

is a fundamental matrix. Since the matrix

$$
Q_{0}=X_{0}(0)-X_{0}(4)=\left(\begin{array}{cccc}
0 & 0 & 0 & 0 \\
80 & 0 & -80 & 0 \\
80 & 0 & -80 & 0 \\
0 & 0 & 0 & 0
\end{array}\right)
$$

is degenerate, for the boundary value problem (12) the critical case is true:

$$
P_{Q_{0}^{*}}=\frac{1}{2}\left(\begin{array}{cccc}
2 & 0 & 0 & 0 \\
0 & 1 & -1 & 0 \\
0 & -1 & 1 & 0 \\
0 & 0 & 0 & 2
\end{array}\right) \neq 0
$$


In this case the matrix $A(k)$ - is rectangular and

$$
P_{A}=\left(\begin{array}{cccc}
0 & 0 & 0 & 0 \\
0 & 0 & 0 & 0 \\
0 & 0 & 0 & 0 \\
0 & 0 & 0 & 1
\end{array}\right), \quad P_{A_{\rho_{0}}}=\left(\begin{array}{l}
0 \\
0 \\
0 \\
1
\end{array}\right) \neq 0
$$

therefore, the desired solution depends on an arbitrary bounded function. We assume that

$$
\Psi(t):=\left(\begin{array}{ccc}
1 & \sin \frac{\pi k}{2} & \cos \frac{\pi k}{2}
\end{array}\right),
$$

and also

$$
\mathcal{D}_{0}=\left(\begin{array}{ccccccc}
0 & 0 & 0 & 0 & 1 & 1 & 0 \\
80 & 0 & -80 & 0 & 2 & 2 & 2 \\
80 & 0 & -80 & 0 & 1 & 1 & 0 \\
0 & 0 & 0 & 0 & -1 & 0 & -1
\end{array}\right)
$$

Since condition

$$
P_{Q_{0}^{*}} \neq 0, \quad P_{\mathcal{D}_{0}^{*}}=0,
$$

is satisfied, the algebraic boundary value problem (12) is reduced to the noncritical case, therefore, according to corollary 2 , the boundary value problem (12) is solvable. The solution of the boundary value problem

$$
z\left(k, c_{r}\right)=X_{r}(k) c_{r}+G\left[f(j) ; \Psi_{0}(j) ; \alpha\right](k), \quad c_{r} \in \mathbb{R}^{2}
$$

is determined by

$$
X_{r}(k)=\left(\begin{array}{cc}
\cos \frac{\pi k}{2}+2 \sin \frac{\pi k}{2} & -2 \sin \frac{\pi k}{2} \\
5 \sin \frac{\pi k}{2} & 2 \cos \frac{\pi k}{2}-2 \sin \frac{\pi k}{2} \\
\cos \frac{\pi k}{2}+2 \sin \frac{\pi k}{2} & -2 \sin \frac{\pi k}{2} \\
0 & 0
\end{array}\right)
$$

the fundamental matrix of solutions of the homogeneous part of the boundary value problem (12), as well as

$$
\begin{gathered}
G\left[f(j), \Psi_{0}(j), \alpha\right](0)=G\left[f(j), \Psi_{0}(j), \alpha\right](1)=G\left[f(j), \Psi_{0}(j), \alpha\right](4)=0, \\
G\left[f(j), \Psi_{0}(j), \alpha\right](2)=\left(\begin{array}{l}
0 \\
1 \\
0 \\
0
\end{array}\right), G\left[f(j), \Psi_{0}(j), \alpha\right](3)=\left(\begin{array}{c}
-1 \\
-2 \\
-1 \\
2
\end{array}\right)
\end{gathered}
$$

the Green operator of a boundary value problem (12). 
The results obtained, similarly $[1,2,9,10,11,12]$ can be used in the theory of nonlinear Noetherian boundary value problems for systems of difference-algebraic equations. In the case of insolvability, the difference-algebraic boundary value problems can be regularized analogically to $[13,14,15]$. In addition, the results obtained similarly to [16] can be used in the theory of stability for systems of difference equations.

Acknowledgement. This work was supported by the Ministry of Education and Science of Ukraine. 0118U003390.

\section{ORCID ID}

S. M. Chuiko (iD https://orcid.org/0000-0001-7186-0129

Ya. V. Kalinichenko (iD https://orcid.org/0000-0002-8352-1965

M. V.Popov (iD https://orcid.org/0000-0001-9106-2650

\section{REFERENCES}

1. A.A. Boichuk. Boundary-value problems for systems of difference equations, Ukrainian Mathematical Journal. - 1997. - 6. V. 49. - P. 832-835.

2. S.L. Campbell. Limit behavior of solutions of singular difference equations, Linear algebra and its appl. - 1979. - V. 23. - P. 167-178.

3. S.M. Chuiko. On a reduction of the order in a differential-algebraic system, Journal of Mathematical Sciences. - 2018. - 1. - V. 235. - P. 2-18.

4. A.A. Boichuk, A.M. Samoilenko. Generalized inverse operators and Fredholm boundary-value problems; 2-th edition. 2016. Boston, De Gruyter, Berlin, 298 p.

5. V.K. Romanko. Difference equations. 2014. Bean, Moscow, 112 p.

6. S.M. Chuiko. A generalized matrix differential-algebraic equation, Journal of Mathematical Sciences (N.Y.). - 2015. - 1. V. 210. - P. 9-21.

7. A.A. Boichuk, V.F. Zhuravlev, A.M. Samoilenko Normally solvable boundary value problems. 2019. Scientific Opinion, Kiev, 628 p.

8. S.M. Chuiko. A Generalized Green operator for a boundary value problem with impulse action, Differential Equations. - 2001. - 8. V. 37. - P. 1189-1193.

9. V.Ya. Gutlyanskii, V.I. Ryazanov, A.S. Yefimushkin. On the boundary-value problems for quasiconformal functions in the plane, Journal of Mathematical Sciences. - 2016. - V. 214. - P. 200-219.

10. S.M. Chuiko. Weakly nonlinear boundary value problem for a matrix differential equation, Miskolc Mathematical Notes. - 2016. - 1. V. 17. - P. 139150 . 
11. I.I.Skrypnik. Removability of isolated singularities for anisotropic elliptic equations with gradient absorption, Israel Journal of Mathematics, - 2016. 1. V. 217. - P. 163-179.

12. S.M.Chuiko. Nonlinear matrix differential-algebraic boundary value problem, Lobachevskii Journal of Mathematics. - 2017. - 2. V. 38. - P. 236-244.

13. A.N. Tikhonov, V.Ya. Arsenin. Solution of Ill-Posed Problems. 1986. Winston, Washington, $288 \mathrm{p}$.

14. S.M. Chuiko. On the regularization of a linear Fredholm boundary-value problem by a degenerate pulsed action, Journal of Mathematical Sciences. 2014. - 1. V. 197. - P. 138-150.

15. S.M.Chuiko, Ya.V. Kalinichenko. On the question of the regularization of the Cauchy problem for a system of linear difference equations, Visnyk of V.N.Karazin Kharkiv National University Ser. "Mathematics, Applied Mathematics and Mechanics". - 2018. - V. 28. - P. 27-34.

16. V.I. Korobov, M.O. Bebiya. Stabilization of one class of nonlinear systems, Automation and Remote Control. - 2017. - 1. V.78. - P. 20-25.

S.M. Chuiko, Ya.V.Kalinichenko, N.V.Popov. Boundary-value problem for a system of nonsingular difference-algebraic equations. The study of differentialalgebraic boundary value problems was initiated in the works of K. Weierstrass, N.N. Luzin and F.R. Gantmacher. Systematic study of differential-algebraic boundary value problems is devoted to the work of S. Campbell, Yu.E. Boyarintsev, V.F. Chistyakov, A.M. Samoilenko, M.O. Perestyuk, V.P. Yakovets, O.A. Boichuk, A. Ilchmann and T. Reis. The study of the differential-algebraic boundary value problems is associated with numerous applications of such problems in the theory of nonlinear oscillations, in mechanics, biology, radio engineering, theory of control, theory of motion stability. At the same time, the study of differential algebraic boundary value problems is closely related to the study of boundary value problems for difference equations, initiated in A.A. Markov, S.N. Bernstein, Ya.S. Besikovich, A.O. Gelfond, S.L. Sobolev, V.S. Ryaben'kii, V.B. Demidovich, A. Halanay, G.I. Marchuk, A.A. Samarskii, Yu.A. Mitropolsky, D.I. Martynyuk, G.M. Vayniko, A.M. Samoilenko, O.A. Boichuk and O.M. Stanzhitsky. Study of nonlinear singularly perturbed boundary value problems for difference equations in partial differences is devoted to the work of V.P. Anosov, L.S. Frank, P.E. Sobolevskii, A.L. Skubachevskii and A. Asheraliev. Consequently, the actual problem is the transfer of the results obtained in the articles by S. Campbell, A.M. Samoilenko and O.A. Boichuk on linear boundary value problems for difference-algebraic equations, in particular finding the necessary and sufficient conditions for the existence of the desired solutions, and also the construction of the Green's operator of the Cauchy problem and the generalized Green operator of a linear boundary value problem for a difference-algebraic equation. The solvability conditions are found in the paper, as well as the construction of a generalized Green operator for the Cauchy problem for a difference-algebraic system. The solvability conditions are found, as well as the construction of a generalized Green 
operator for a linear Noetherian difference-algebraic boundary value problem. An original classification of critical and noncritical cases for linear difference-algebraic boundary value problems is proposed.

Keywords: boundary-value problems; difference-algebraic equations; pseudoinverse matrices.

Чуйко С. М., Калініченко Я. В., Попов М.В. Крайові задачі для систем невироджених різницево-алгебраїчних рівнянь. Дослідження диференціальноалгебраїчних крайових задач започатковане у роботах К. Вейєрштрасса, М.М. Лузіна та Ф.Р. Гантмахера. Систематичному вивченню диференціально-алгебраїчних крайових задач присвячені роботи С. Кемпбелла, Ю.Є. Бояринцева, В.Ф. Чистякова, А.М. Самойленка, М.О. Перестюка, В.П. Яковця, О.А. Бойчука, А. Ілчманна та Т. Рейса. Вивчення диференціально-алгебраїчних крайових задач пов'язане з численними застосуваннями таких задач у теорії нелінійних коливань, у механіці, біології, радіотехніці, теорії керування, теорії стійкості руху. В той же час дослідження диференціально-алгебраїчних крайових задач тісно пов'язане з дослідженням крайових задач для різницевих рівнянь, започаткованим у роботах А.А. Маркова, С.Н. Бернштейна, Я.С. Безиковича, О.О. Гольфонда, С.Л. Соболєва, В.С. Рябенького, В.Б. Демідовича, А. Халаная, Г.І. Марчука, О.А. Самарського, Ю.О. Митропольського, Д.І. Мартинюка, Г.М. Вайніко, А.М. Самойленка, О.А. Бойчука та О.М. Станжицького. Дослідженню нелінійних сингулярно збурених крайових задач для різницевих рівнянь у частинних різницях присвячені роботи В.П. Аносова, Л.С. Франка, П.Є. Соболєвського, О.Л. Скубачевського та А. Ашералієва. Отже, актуальною проблемою $є$ перенесення результатів, отриманих у статтях С. Кемпбелла, А.М. Самойленка та О.А. Бойчука на лінійні крайові задачі для різницево-алгебраїчних рівнянь, зокрема, знаходження необхідних та достатніх умов існування шуканих розв'язків, а також, конструкції оператора Гріна задачі Коші та узагальненого оператора Гріна лінійної крайової задачі для різницево-алгебраїчного рівняння. У статті знайдено умови розв'язності, а також конструкцію узагальненого оператора Гріна задачі Коші для різницево-алгебраїчної системи. Знайдено умови розв'язності, а також конструкцію узагальненого оператора Гріна для лінійної нетерової різницевоалгебраїчної крайової задачі. Запропоновано оригінальну класифікацію критичних і некритичних випадків для лінійних різницево-алгебраїчних крайових задач. Ключові слова: крайові задачі; різницево-алгебраїчні рівняння; псевдообернена матриця.

Article history: Received: 30 August 2019; Final form: 21 November 2019; Accepted: 21 November 2019. 